\title{
Comparative Study of Ni(II) and Cu(II) Adsorption by As- Prepared and Oxidized Multi-Walled N-Doped Carbon Nanotubes
}

\author{
Renata Balog ${ }^{1}$, Viktoria Simon ${ }^{2}$, Maryna Manilo ${ }^{3}$, Laszlo Vanyorek ${ }^{3}$, \\ Zoltan Csoma ${ }^{1}$, and Sandor Barany ${ }^{1,3,4}$ \\ ${ }^{1}$ Ferenc Rakoczi II. Transcarpathian Hungarian Institute, \\ 6 Kossuth Square, \\ UA-90200 Beregszász, Transcarpathia, Ukraine \\ ${ }^{2}$ F. D. Ovcharenko Institute of Biocolloidal Chemistry, N.A.S. of Ukraine, \\ 42 Academician Vernadsky Blvd., \\ UA-03142 Kyiv, Ukraine \\ ${ }^{3}$ Institute of Chemistry, University of Miskolc, \\ Miskolc-Egyetemvaros, \\ 3515 Miskolc, Hungary \\ ${ }^{4} M T A-M E$ Materials Science Research Group, \\ Miskolc-Egyetemvaros, \\ 3515 Miskolc, Hungary
}

The laws and mechanisms of adsorption of $\mathrm{Ni}(\mathrm{II})$ and $\mathrm{Cu}(\mathrm{II})$ ions by wellcharacterized as-prepared and oxidized N-doped multi-walled carbon nanotubes (N-CNTs) are described and discussed. The samples are synthesized by catalytic chemical vapour deposition method using $n$-butylamine as carbon source and $\mathrm{Ni}\left(\mathrm{NO}_{3}\right)_{2}+\mathrm{MgO}$ as catalyst and purified by treatment with $\mathrm{HCl}$. The surface functionalization is performed using oxidation with mixture of concentrated $\mathrm{H}_{2} \mathrm{SO}_{4}$ and $\mathrm{HNO}_{3}$. As shown, adsorption of $\mathrm{Ni}(\mathrm{II})$ and $\mathrm{Cu}(\mathrm{II})$ reaches equilibrium value within $20-30 \mathrm{~min}$; adsorption results in a moderate decrease in the suspension $\mathrm{pH}$ for pristine N-CNTs (1.0-1.5 $\mathrm{pH}$ unit) and a considerable lowering the $\mathrm{pH}$ for oxidized sample (up to $2.5 \mathrm{pH}$ unit); the adsorption isotherms are described by the Langmuir equation; the plateau amounts of adsorption $(25-30 \mathrm{mg} / \mathrm{g}$ for $\mathrm{Cu}$ and $35-$ $40 \mathrm{mg} / \mathrm{g}$ for $\mathrm{Ni}$ ) are almost the same for both as-prepared and oxidized samples; at $\mathrm{pH} 8.0$ and higher for $\mathrm{Ni}$ and $\mathrm{pH} 6.5$ and higher for $\mathrm{Cu}$ ions, a sharp increase in adsorption is observed that is caused by the hydroxides' precipitation. The spectroscopic, adsorption, electrophoretic and $\mathrm{pH}$ measurements' data testify that below $\mathrm{pH}$ of hydroxide precipitation, the major mechanism of adsorption by as-prepared N-CNTs is the donoracceptor interaction between the free electron pair of $\mathrm{N}$ atoms incorporated into nanotubes' lattice and vacant $d$-orbital of the adsorbing $\mathrm{Ni}(\mathrm{II})$ 
or $\mathrm{Cu}(\mathrm{II})$ ions. For the oxidized N-CNTs, ion-exchange processes with a release of $\mathrm{H}^{+}$may play minor role.

В роботі розглянуто закони та механізми адсорбції йонів $\mathrm{Ni}$ (II) та $\mathrm{Cu}$ (II) охарактеризованими вихідними та окисненими $\mathrm{N}$-легованими багатостінними вуглецевими нанорурками (N-CNT). Зразки синтезували методою каталітичного хемічного осадження пари $n$-бутиламіну як джерела Карбону та $\mathrm{Ni}\left(\mathrm{NO}_{3}\right)_{2}+\mathrm{MgO}$ як каталізатора 3 подальшою очисткою їх HCl. Функціоналізацію поверхні N-CNT проводили за допомогою окиснення сумішшю концентрованих $\mathrm{H}_{2} \mathrm{SO}_{4}$ та $\mathrm{HNO}_{3}$. Було показано, що: адсорбція йонів $\mathrm{Ni}(\mathrm{II})$ та $\mathrm{Cu}(\mathrm{II})$ досягає рівноважного значення протягом 20-30 хв.; адсорбція приводить до помірного зменшення $\mathrm{pH}$ суспензії для вихідних $(1,0-1,5$ одиниці $\mathrm{pH})$ та значного пониження $\mathrm{pH}$ (до 2,5 одиниць $\mathrm{pH}$ ) для окиснених N-CNT-зразків; ізотерми адсорбції описуються Ленг'мюровим рівнянням; положення плато адсорбції (2530 мг/г для $\mathrm{Cu}$ та 35-40 мг/г для $\mathrm{Ni}$ ) майже однакове як для вихідних, так і для окиснених зразків; при $\mathrm{pH} \geq 8,0$ для йонів $\mathrm{Ni}$ та $\mathrm{pH} \geq 6,5$ для йонів $\mathrm{Cu}$ спостерігається різке збільшення величини адсорбції за рахунок осадження гідроксидів. Дані спектроскопічних, адсорбційних, електрофоретичних і pH-мірянь свідчать про те, при $\mathrm{pH}$, нижчих за значення, при якому відбувається осадження гідроксидів, основним механізмом адсорбції вихідними N-CNT є донорно-акцепторна взаємодія між вільною парою електронів атомів Нітрогену, розміщених на гратниці нанорурок, та вакантною $d$-орбіталлю йонів $\mathrm{Ni}$ (II) або $\mathrm{Cu}$ (II) відповідно. Для окиснених N-CNT процеси йонообміну з вивільненням $\mathrm{H}^{+}$ відіграють незначну роль.

В работе рассмотрены законы и механизмы адсорбции ионов $\mathrm{Ni}$ (II) и $\mathrm{Cu}(\mathrm{II})$ охарактеризованными исходными и окислёнными легированными азотом многослойными углеродными нанотрубками (N-CNT). Образцы синтезировали методом каталитического химического осаждения паров $\mathrm{N}$-бутиламина (источник углерода) и $\mathrm{Ni}\left(\mathrm{NO}_{3}\right)_{2}+\mathrm{MgO}$ (катализатор) с последующей их очисткой $\mathrm{HCl}$. Функционализация поверхности N-CNT проводилась с помощью окисления смесью концентрированных $\mathrm{H}_{2} \mathrm{SO}_{4}$ и $\mathrm{HNO}_{3}$. Было показано, что: адсорбция ионов $\mathrm{Ni}$ (II) и $\mathrm{Cu}$ (II) достигает равновесного значения в течение 20-30 мин; адсорбция приводит к умеренному уменьшению $\mathrm{pH}$ суспензии на исходных $(1,0-1,5$ единицы $\mathrm{pH}$ ) и значительному снижению $\mathrm{pH}$ (до 2,5 единиц $\mathrm{pH}$ ) для окислённых N-CNT-образцов; изотермы адсорбции описываются уравнением Ленгмюра; положение плато адсорбции (25-30 мг/г для $\mathrm{Cu}$ и 35-40 мг/г для $\mathrm{Ni}$ ) почти одинаково как для исходных, так и для окислённых образцов; при $\mathrm{pH} \geq 8,0$ для ионов $\mathrm{Ni}$ и $\mathrm{pH} \geq 6,5$ для ионов $\mathrm{Cu}$ наблюдается резкое увеличение величины адсорбции за счёт осаждения гидроксидов. Данные спектроскопических, адсорбционных, электрофоретических и $\mathrm{pH}$-измерений показывают, что при $\mathrm{pH}$ ниже значения, при котором происходит осаждение гидроксидов, основным механизмом адсорбции исходными N-CNT является донорноакцепторное взаимодействие между свободной парой электронов атомов азота, размещённых на решётке нанотрубок, и вакантной $d$-орбиталью 
ионов $\mathrm{Ni}(\mathrm{II})$ или $\mathrm{Cu}(\mathrm{II})$ соответственно. Для окислённых N-CNT процессы ионообмена с высвобождением $\mathrm{H}^{+}$играют незначительную роль.

Key words: $\mathrm{N}$-doped multi-walled carbon nanotubes, $\mathrm{Ni}$ (II) and $\mathrm{Cu}(\mathrm{II})$ ions, adsorption, kinetics.

Ключові слова: $\mathrm{N}$-леговані багатошарові вуглецеві нанорурки, йони $\mathrm{Ni}(\mathrm{II})$ та $\mathrm{Cu}(\mathrm{II})$, адсорбція, кінетика.

Ключевые слова: $\mathrm{N}$-легированные многослойные углеродные нанотрубки, ионы $\mathrm{Ni}(\mathrm{II})$ и $\mathrm{Cu}(\mathrm{II})$, адсорбция, кинетика.

(Received 4 December, 2019; in final version, 31 January, 2020)

\section{INTRODUCTION}

Among variety of practical applications of carbon nanotubes (CNTs), an increasing important segment is related to their use as sorbents for toxic substances, heavy metal ions, and organic compounds [1]. For example, CNTs are intensely studied as sorbents for water purification from individual nickel and lead [2], copper and cobalt [3], chromium [4] ions, and other individual or mixed ions of different metals [5].

Nickel (II) is a hazardous heavy metal ion, which is increasingly accumulated in potable, ground and wastewaters. Copper is an essential nutrient, for which the World Health Organization (WHO, 1998) recommends a daily intake of $30 \mu \mathrm{g} / \mathrm{kg}$ body weight. Drinking water standards have been established to prevent adverse health effects resulting from ingestion of too much copper. WHO (1998) recommends a limit of $2 \mathrm{mg} / \mathrm{dm}^{3} \mathrm{Cu}$ to prevent adverse health effects from copper exposure. There are numerous studies devoted to extraction of these ions by single-walled (SWCNTs) or multi-walled carbon nanotubes (MWCNTs), both pristine and oxidized by different agents. The kinetics of adsorption, shape of adsorption isotherms, impact of $\mathrm{pH}$ and degree of CNT surface functionalization has been elucidated. A short review of the recent results obtained is summarized below.

Authors [6, 7] have shown that the adsorption of Ni(II) onto oxidized CNTs is strongly dependent on $\mathrm{pH}$ and nanotubes concentration and, to a lesser extent, ionic strength. The adsorption data well fit the Langmuir model, and the adsorbed $\mathrm{Ni}$ (II) can be easily desorbed at $\mathrm{pH}<2.0$. It was speculated that ion exchange might be the predominant mechanism of $\mathrm{Ni}$ (II) adsorption on oxidized CNTs. Adsorption of $\mathrm{Ni}$ (II) on oxidized CNTs was increased from zero to 99\% at $\mathrm{pH}$ 2.0-9.0 and then maintained the high level with increasing $\mathrm{pH}$. The adsorption achieved equilibrium within $2 \mathrm{~h}$ [7]. 
The mechanism of adsorption was attributed to surface complexation and ion exchange. It was also shown that the adsorption capacity for nickel ions from aqueous solutions increased significantly onto the surface of the oxidized CNTs compared to that on the asproduced CNTs, and the maximum adsorption by these adsorbents was determined as 18.08 and $49.26 \mathrm{mg} / \mathrm{g}$, respectively [8]. The number of functional groups, total acidic sites and negatively charged carbons on CNTs surface were greatly increased after oxidation by $\mathrm{NaOCl}$, which resulted in sorption of more $\mathrm{Ni}$ ions [9]. Typically, $60-95 \%$ of $\mathrm{Ni}$ (II) can be extracted from aqueous solution by MWCNTs depending on the initial solution concentrations [10]. As suggested by the distribution coefficient values, increased initial $\mathrm{Ni}$ (II) solution concentrations resulted in lower adsorption, while the total amount of ions removed from the equilibrating solutions increased.

Higher adsorption was observed at $\mathrm{pH}>6.0$, and the sorption process reached equilibrium at $60 \mathrm{~min}$. The sorption mechanisms are complicated and appear attributable to electrostatic forces and chemical interactions between the nickel ions and the surface functional groups of the CNTs [10].

Carbon nanotubes were shown to possess good adsorption properties and high capacity $\left(3.5 \mathrm{mg} / \mathrm{g}\right.$ at initial concentration of $\mathrm{Cu}^{2+}$ ions of $20 \mathrm{mg} / \mathrm{dm}^{3}$ ) in respect to $\mathrm{Cu}(\mathrm{II})$ ions. The affinity of this ion to the CNT surface and the adsorbed amounts were found to be higher compared to other heavy metal ions such as $\mathrm{Co}, \mathrm{Zn}, \mathrm{Pb}, \mathrm{Mn}$. The adsorption data were well described by the Freundlich isotherm [11].

The adsorption capacity of oxidized N-doped bamboo like MWCNTs in respect to $\mathrm{Cu}(\mathrm{II})$ ions reached $15 \mathrm{mg} / \mathrm{g}$ [12]. Authors $[13,14]$ have shown that the interaction of $\mathrm{Cu}(\mathrm{II})$ ions deposited on the N-CNT surface by thermal decomposition of copper acetate is realized via their strong coordination by pyridine nitrogen atoms at the edge of the graphene sheets of the adsorbent reviewed the laws and mechanisms of sorption of divalent metal ions $\left(\mathrm{Cd}^{2+}, \mathrm{Cu}^{2+}, \mathrm{Ni}^{2+}\right.$, $\mathrm{Pb}^{2+}$, and $\mathrm{Zn}^{2+}$ ) from aqueous solution by various kinds of raw and surface oxidized carbon nanotubes. The sorption mechanisms appear mainly attributable to chemical interactions between the metal ions and the surface functional groups of the CNTs. The sorption capacities of CNTs remarkably increased after oxidized by $\mathrm{NaOCl}, \mathrm{HNO}_{3}$ and $\mathrm{KMnO}_{4}$ solutions and reached, for example, $6.9 \mathrm{Ni} \mathrm{mg} / \mathrm{g}$ and $47.8 \mathrm{Ni} \mathrm{mg} / \mathrm{g}$ onto CNTs oxidized by $\mathrm{HNO}_{3}$ or $\mathrm{NaOCl}$, respectively. Similar results were obtained by authors [15], who have shown that MWCNTs can be successfully used for the removal of heavy metals from aqueous solution. A competition among the metal ions for binding was revealed on the MWCNTs surface with affinity in the 
order: $\mathrm{Cu}$ (II) $>\mathrm{Zn}$ (II) $>\mathrm{Pb}$ (II) $>\mathrm{Cd}$ (II). Authors [16] have analysed in detail the impact of CNTs properties (adsorption sites, pore volume, BET surface area, surface total acidity) and solution properties (ionic strength, effect of $\mathrm{pH}$ ) on the adsorption of heavy metal ions by carbon nanotubes. The contribution of physical adsorption, electrostatic attraction, precipitation and chemical interaction between the metal ions and the surface functional groups of CNTs was discussed.

Gao et al. [17] measured the adsorption isotherms of $\mathrm{Cu}(\mathrm{II})$, $\mathrm{Ni}(\mathrm{II}), \mathrm{Zn}(\mathrm{II})$ and $\mathrm{Cd}(\mathrm{II})$ onto carbon nanotubes oxidized by concentrated $\mathrm{HNO}_{3}$ in single, binary, ternary and quaternary systems, and have shown that isotherms reveal the effect of competition for adsorption sites seen as a decrease in the amount adsorbed. The uptakes at the equilibrium concentration of $0-0.04 \mathrm{mmole} / \mathrm{dm}^{3}$ in single system and $0-0.15 \mathrm{mmole} / \mathrm{dm}^{3}$ in binary system are in the order $\mathrm{Cu}^{2+}>\mathrm{Ni}^{2+}>\mathrm{Cd}^{2+}>\mathrm{Zn}^{2+}$ while for the ternary and quaternary, the order is $\mathrm{Cu}^{2+}>\mathrm{Cd}^{2+}>\mathrm{Zn}^{2+}>\mathrm{Ni}^{2+}$.

Summarizing the literature review, we can say that the major factors affecting the adsorption of $\mathrm{Ni}$ (II) and $\mathrm{Cu}$ (II) by carbon nanotubes and the mechanisms of the process are at large clarified. At the same time, surprisingly, there is a lack of information about the laws and mechanisms of adsorption of these ions by $\mathrm{N}$-doped carbon nanotubes, i.e. adsorbents containing surface $\mathrm{N}$ atoms in different state, potentially capable to form complexes with $\mathrm{Ni}$ (II) and $\mathrm{Cu}(\mathrm{II})$ ions. We tried to fill in, at least in part, this gap.

\section{MATERIALS AND METHODS}

\subsection{Materials}

\subsubsection{Synthesis and Functionalization of $N$-Doped Carbon Nanotubes}

The $\mathrm{N}$-doped carbon nanotubes (N-CNTs) were synthesized by catalytic Chemical Vapour Deposition method using n-butylamine (VWR) as carbon source and $\mathrm{Ni}\left(\mathrm{NO}_{3}\right)_{2} \cdot 6 \mathrm{H}_{2} \mathrm{O}$ (Sigma Aldrich) plus magnesium oxide, $\mathrm{MgO}$ (Merck) as catalyst materials, as described in the paper [12]. The product was purified from the catalyst by treatment with concentrated hydrochloride acid (VWR). The surface functionalization of N-CNTs was performed using oxidation with mixture of concentrated sulphuric acid and nitric acid $(V / V=3: 1)$ at $80^{\circ} \mathrm{C}$ overnight using continuous stirring. After the acidic treatment, the N-CNTs were filtered and washed with distilled water until pH 5.0-6.0 was reached, then dried at $120^{\circ} \mathrm{C}$. The mixture of $\mathrm{H}_{2} \mathrm{SO}_{4}$ and $\mathrm{HNO}_{3}$ turned out to be very efficient for oxidation of carbon nanotubes, as it was shown in our previous work [18]. 


\subsubsection{Characterization of N-Doped Carbon Nanotubes}

The image of the N-CNTs obtained by High Resolution Transmission Electron microscopy-HRTEM (FeiTechnai G2, $200 \mathrm{kV}$ ) was shown in Fig. 1. Figure 1, $a$ shows that non-oxidized N-CNTs represent uneven fibres with length of $2-3 \mu \mathrm{m}$, and diameter between 7 $\mathrm{nm}$ and $22 \mathrm{~nm}$, with a mean value of $12.4 \mathrm{~nm}$. As a result of oxidative treatment, the N-CNTs fibres were broken into shorter fibres, with about 200-800 $\mathrm{nm}$ sections in length (Fig. 1, b). This can be attributed to the fact that the $\mathrm{N}$-doped bamboo-like carbon nanotubes are easily ruptured, because their mechanical strength is lower compared to their non-doped counterparts.

The extraordinary structure of these nanotubes is demonstrated on their schematic illustration (Fig. 1, c). A number of graphene edges are seen on the wall of N-CNTs, containing $s p^{3}$ carbon atoms and nitrogen atoms, which easily react with oxidants (Fig. $1, d$ ). In this sense, the N-CNTs can be oxidized to higher extent than the non-doped, conventional MWCNTs or SWCNTs. The fibre edges can serve as high energy adsorption sites on the wall of bamboo-like nanotubes, which are easily accessible for different ions or molecules and can form relatively strong bounds with the adsorbent surface (due to ion exchange adsorption, surface complexes or $\pi-\pi$ interactions).

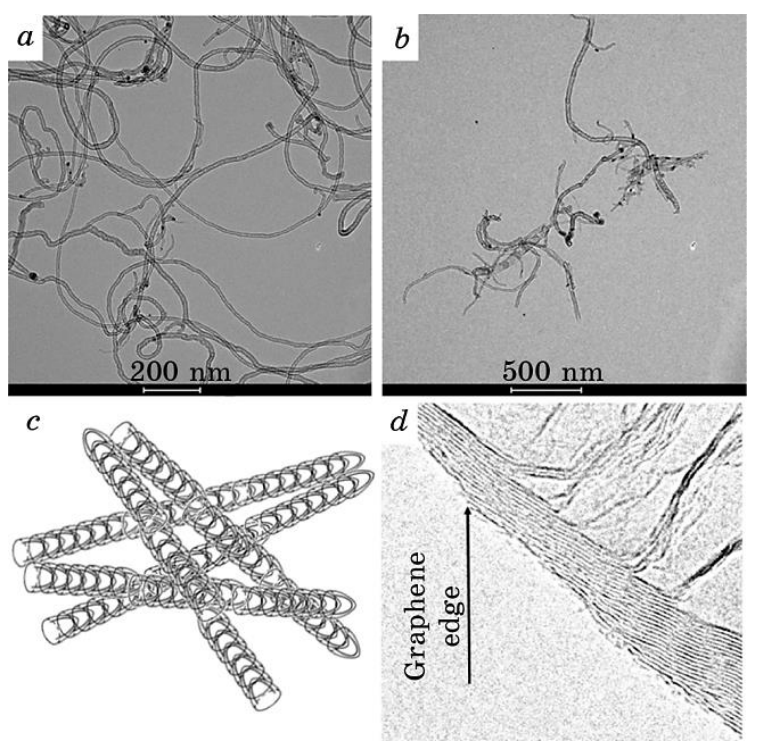

Fig. 1. HRTEM image of the non-oxidized $(a)$ and oxidized $(b)$ N-CNTs; schematic illustration of the bamboo-like structure $(c)$; the graphene edges on the CNTs wall $(d)$. 
X-Ray Photoelectron Spectroscopy-XPS (SPECS instrument with PHOIBOS 150 MCD 19 detector) and Fourier-transform infrared spectroscopy-FTIR (A VERTEX 70 FTIR spectrometer, Bruker, Germany) measurements were applied to identify the binding types and the nature of surface functional groups.

Figure 2 shows the XPS spectra of the non-oxidized and oxidized $\mathrm{N}$-CNTs characterizing the binding energy of the $\mathrm{C}-\mathrm{N}$ and $\mathrm{C}-\mathrm{O}$ bounds. The peak at $398.6 \mathrm{eV}$ binding energy can be attributed to the pyridine type nitrogen atoms (Fig. 2, $a$ ), the next peak at 401.1 $\mathrm{eV}$ originates from the graphitic nitrogen incorporation. A peak of the oxidized nitrogen (pyridine $\mathrm{N}^{+}-\mathrm{O}^{-}$species) can be also observed on the spectrum at the binding energy of $404.7 \mathrm{eV}$. The $\mathrm{N}$-doped CNTs are easily oxidized at crystal distortions in the graphitic structure. During the acidic treatment oxygen containing functional groups are developed, which are located at the $\mathrm{C} 1 s$ band (Fig. 2, b). The appearance of $-\mathrm{C}=\mathrm{C}-$ and $-\mathrm{C}-\mathrm{C}-$ bounds is reflected by a highly intensive peak at $284.6 \mathrm{eV}$, and the $\mathrm{C}=\mathrm{O}$ peak was identified at
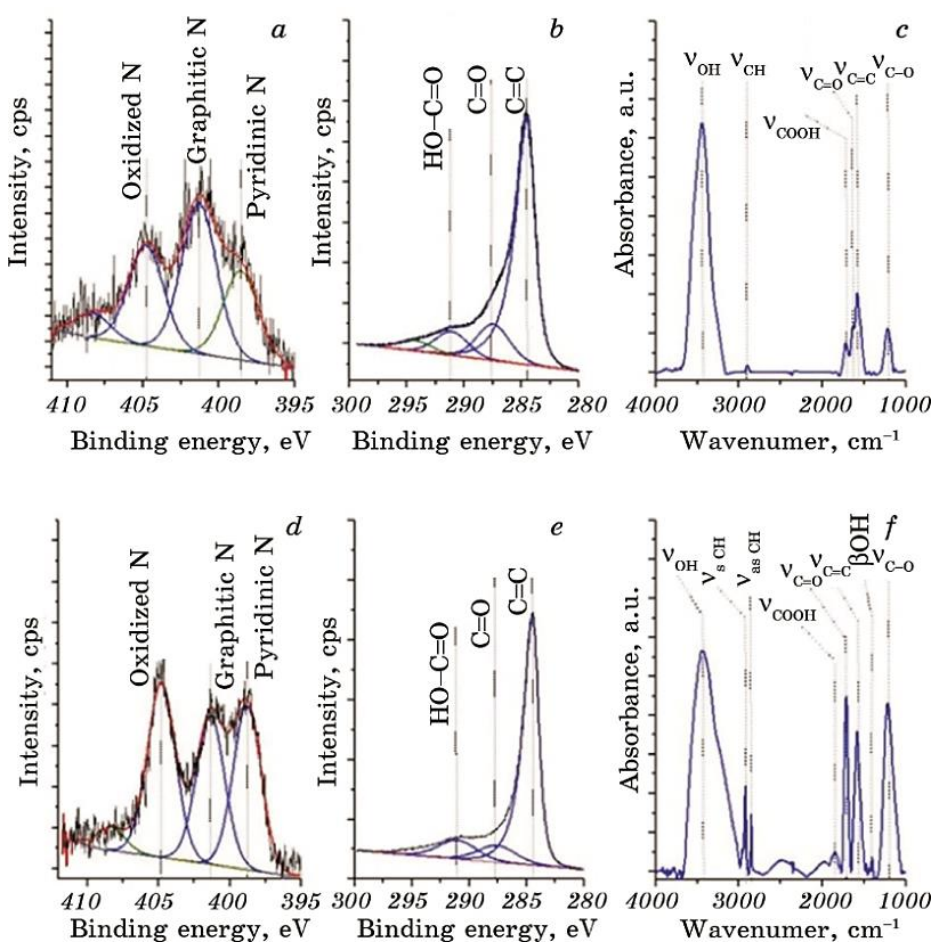

Fig. 2. XPS spectra with deconvoluted $\mathrm{N} 1 s$ band of the non-oxidized ( $a$ ) and oxidized $(d) \mathrm{N}$-CNTs and $\mathrm{C} 1 s$ band of the non-oxidized $(b)$ and oxidized (e) N-CNTs. FTIR spectrum of the non-oxidized $(c)$ and oxidized $(f) \mathrm{N}$ CNTs. 
$287.5 \mathrm{eV}$ (Fig. 2, b). The peak of the carboxyl groups is shown at the binding energy of $291.2 \mathrm{eV}$. These oxygen-containing functional groups are visible on the FTIR spectra (Figs. 2, $c, f$ ): stretching vibration of the $\mathrm{C}-\mathrm{O}$ bond at $1205 \mathrm{~cm}^{-1}$, carbonyl bond at 1628.7 $\mathrm{cm}^{-1}$, carboxyl groups at $1713.7 \mathrm{~cm}^{-1}$ and hydroxyl groups at 3440.7 $\mathrm{cm}^{-1}$ (Fig. 2,c). The latter bond is originated from the alcoholic or phenolic hydroxyl groups and from the $-\mathrm{COOH}$ groups. Adsorbed water can contribute to the appearance of this absorption bond as well. The vibration mode of N-CNT structure $\left(v_{\mathrm{C}=\mathrm{C}}\right)$ was also found in the FTIR spectrum at $1565.4 \mathrm{~cm}^{-1}$ wave number.

ZetaSizer Nano ZS instrument (Malvern, United Kingdom) was used for determination of the electrophoretic mobility of N-CNTs in aqueous media $(0.01 \%$ wt., here-and-after $\%)$ at room temperature $(T=298 \mathrm{~K})$ in the range of external electric field gradients of 6-15 $\mathrm{V} / \mathrm{cm}$. The electrophoretic mobility was transformed into $\zeta$-potential using the classical Smoluchowski equation approach with the software of the instrument. The presented values of the $\zeta$-potential were obtained by averaging three to six measurement results; the measurements error was about $3-5 \%$.

Figure 3 shows the pH-dependence of N-CNTs electrokinetic potential in aqueous suspension. For the pristine N-CNT samples, the isoelectric point (IEP) is observed near $\mathrm{pH} \mathrm{7.2,} \mathrm{which} \mathrm{is} \mathrm{higher} \mathrm{than}$ the IEP values reported for regular (no $\mathrm{N}$ atoms in the lattice) $\mathrm{N}$ CNTs: $\mathrm{pH} 4.0$ [19] or $\mathrm{pH} 6.0$ [20]. This means that at lower $\mathrm{pH}$, the surface is charged positively. The positive charge of the surface in acidic media $(\mathrm{pH} 3-7)$ is due to the presence of small amounts of

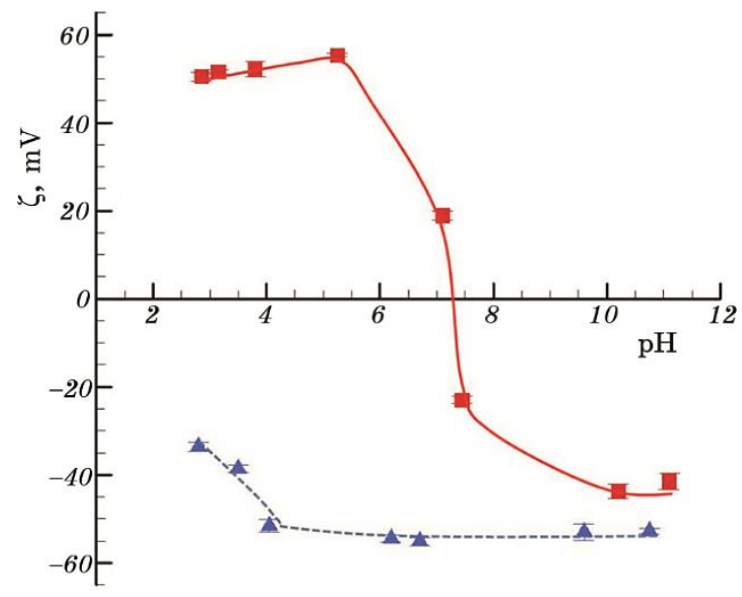

Fig. 3. Dependence of the $\zeta$-potential of the pristine (squares) and oxidized (triangles) N-CNTs on the system $\mathrm{pH}$. Concentration of N-CNTs was $0.01 \%$. 
oxidized species in the original N-CNTs (see spectra in Fig. 2) as well as to the presence of pyridine type $\mathrm{N}$ atoms in the lattice capable to acquire positive charge due to proton transfer. The shift of the IEP to higher values probably reflects the contribution of protonated $\mathrm{N}$-atoms into the CNTs surface charge. After the acid treatment, the IEP is not reached, and the surface charge remains negative in the whole $\mathrm{pH}$ interval studied $(\mathrm{pH} \mathrm{3-12).} \mathrm{This} \mathrm{is} \mathrm{due} \mathrm{to}$ the dissociation of oxidized negative species of various natures on the N-CNTs surface. An increase in the number of oxidized specimen and a decrease in the number of low-oxidized groups formed on the surface overcompensate the contribution of the positive surface charge.

\subsection{Methods: Adsorption Measurements}

$\mathrm{Ni}(\mathrm{II})$ and $\mathrm{Cu}(\mathrm{II})$ ions were adsorbed by the carbon nanotubes (typical adsorbent concentration of $0.1 \%$ ) at room temperature in a $\mathrm{pH}$ range of 2.0-12.0 under mechanical shaking the reaction mixtures for designated period of time. The kinetic dependencies were measured during $36 \mathrm{~h}$. The concentration of nickel and copper ions before and after adsorption was determined in acetylene-air flame with an Agilent 240AA atomic absorption spectrophotometer (Agilent Technologies, US) operating at a wavelength of $429.0 \mathrm{~nm}$ and an optical gap width of $0.5 \mathrm{~nm}$. The chosen conditions enable to determine the concentration of $\mathrm{Ni}$ (II) ions in the range of 1-100 $\mu \mathrm{g} / \mathrm{dm}^{3}$. The adsorbed amount was calculated from the material balance of ions in solution prior and after adsorption.

\section{RESULTS AND DISCUSSION}

\subsection{Kinetics of Adsorption}

Figure 4 demonstrates the time dependencies of adsorption of $\mathrm{Ni}$ (II) and $\mathrm{Cu}(\mathrm{II})$ ions by pristine and oxidized N-CNTs at $\mathrm{pH}$ 5.5. The kinetics of adsorption of heavy-metal ions by carbon-containing sorbents is a rather complex process. Most works consider a twostep adsorption kinetics, i.e., an initial rapid uptake and a much slower second stage of adsorption, which may last for several days and even weeks [21-24]. Some authors reported an optimal contact duration of several minutes [24], while others believe that the optimal time required to establish equilibrium is several hundred hours [21, 23]. Generally, most authors suppose the optimal contact time to be $1-5 \mathrm{~h}[21,22]$.

Three regions can be distinguished on the kinetic dependences of 


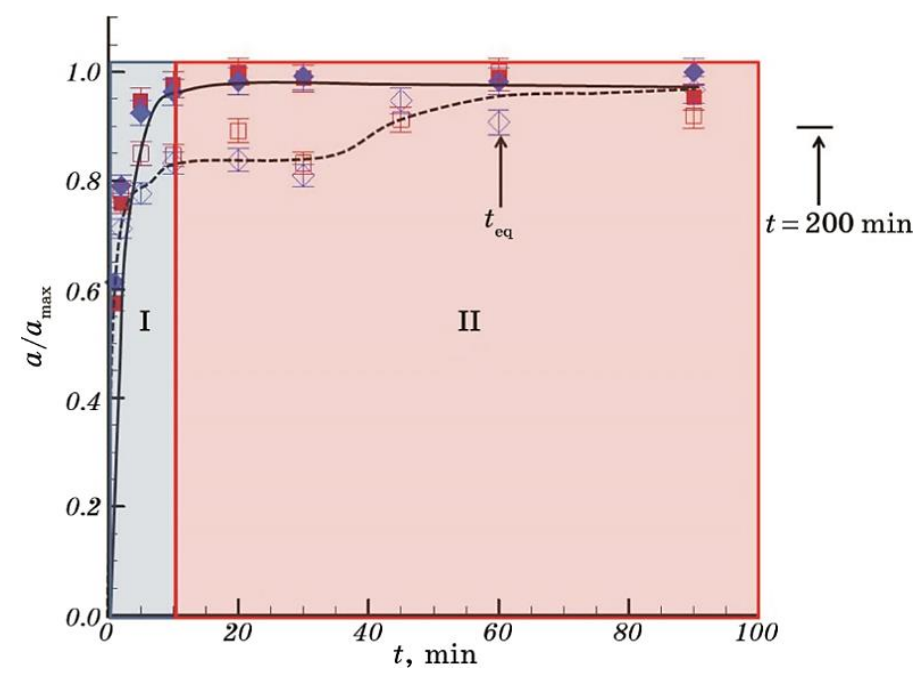

Fig. 4. Time dependences of $\mathrm{Ni}(\mathrm{II})$ (filled symbol) and $\mathrm{Cu}(\mathrm{II})$ (empty symbol) adsorption by the as-prepared (squares) and oxidized (diamonds) $\mathrm{N}$ doped CNTs at $\mathrm{pH}$ 5.5.

adsorption of $\mathrm{Ni}(\mathrm{II})$ and $\mathrm{Cu}(\mathrm{II})$ in our experiments. At N-CNTssolution contact duration $t \leq 10 \mathrm{~min}$ (region I), the specific adsorption drastically increases with time; in a contact-time range of 10100 min (region II), the adsorption equilibrium is established; at $t>100 \mathrm{~min}, \mathrm{Ni}$ (II) ions are in a small amount (up to $10 \%$ ) desorbed from the nanotubes surface and saturation in the adsorption was observed (region III). A further increase in the contact time up to 5 days gave an insufficient change $(2-3 \%)$ in the adsorbed amount. Similar results were obtained while adsorbing $\mathrm{Cr}$ (III) ions on the CNTs surface [25]. Contact time $t_{\mathrm{eq}}=60 \mathrm{~min}$ was chosen to measure the equilibrium adsorption isotherms. The data in Fig. 5 show that this time is enough to establish adsorption equilibrium.

\subsection{Effect of pH}

To estimate the role of ion-exchange processes in the mechanism of adsorption of $\mathrm{Ni}(\mathrm{II})$ and $\mathrm{Cu}(\mathrm{II})$ ions by N-CNTs, it is useful to inspect the changes in the suspension $\mathrm{pH}$ as a result of adsorption of ions. Inspecting the effect of $\mathrm{pH}$ on the adsorption of $\mathrm{Ni}$ (II) and $\mathrm{Cu}$ (II) ions by carbon nanotubes, quite different effects should be considered as follow.

(i) $\mathrm{Ni}$ (II)and $\mathrm{Cu}$ (II) ions in aqueous solutions are hydrated by six water molecules, they possess moderate resistance to hydrolysis. Nickel ions predominantly exist in the form of species with charge 

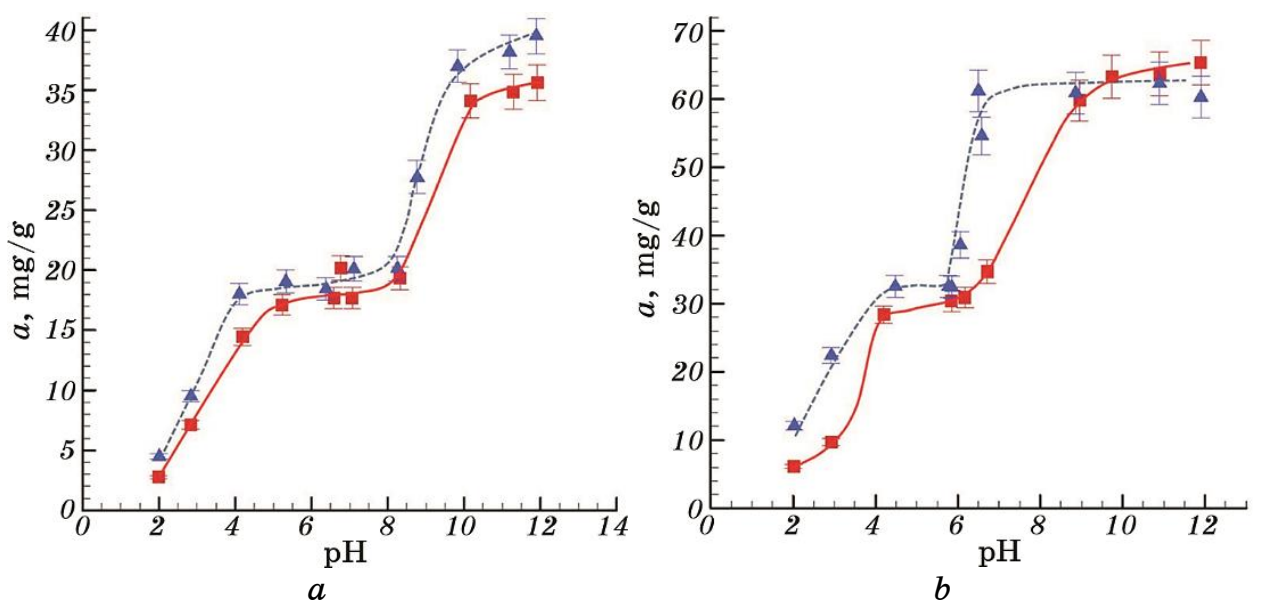

Fig. 5. pH-dependence of the nickel $(a)$ and copper $(b)$ ions' adsorption by as-prepared (squares) and oxidized (triangles) N-CNTs.

$2+$ in dilute solutions and hydrolysis products of $\mathrm{Ni}(\mathrm{OH})^{+}$(the equilibrium constant of formation was determined as -19.8 [26] were found at concentration of salts higher than $5 \cdot 10^{-2} \mathrm{M}$ of $\mathrm{Ni}(\mathrm{II})$ [27]. The type of specimen of copper ions also depended of their concentration and $\mathrm{pH}$ value of solution, i.e., at low concentrations, the dominant species is the copper ion, $\mathrm{Cu}^{2+}$ (up to $\mathrm{pH}$ 7.5), copper hydroxide, $\mathrm{Cu}(\mathrm{OH})_{2}$ (up to $\mathrm{pH} 12.3$ ) and $\mathrm{Cu}(\mathrm{OH})_{3}^{-}(\mathrm{pH} 12.3)$. At higher copper concentrations, solid $\mathrm{Cu}(\mathrm{OH})_{2}$ is formed and precipitates out of solution at copper concentrations above the solubility product of copper hydroxide at $1 \cdot 10^{-8} \mathrm{M}$. It is important to note that the domain of stability of solid $\mathrm{Cu}(\mathrm{OH})_{2}$ is expanding to lower and higher $\mathrm{pH}$ values with increasing copper concentration. A small but significant amount of an important $\mathrm{Cu}$ (II) complex $\mathrm{Cu}(\mathrm{OH})^{+}$is formed at low $\mathrm{pH}(3-7)$ [25]. Obviously, hydrolysis of nickel and copper salt with a release of $\mathrm{H}^{+}$ions results in a change of the surface charge of N-CNTs (see above) and possibly the adsorption of $\mathrm{Ni}$ (II) or $\mathrm{Cu}(\mathrm{II})$ ions.

(ii) Increasing the system $\mathrm{pH}$ gives a rise to the negative surface charge density of N-CNTs and to the adsorption of the positively charged nickel or copper ions via electrostatic mechanism.

(iii) at $\mathrm{pH} 6.5$ or $\mathrm{pH} 7.8-8.0$, the process of precipitation of $\mathrm{Cu}(\mathrm{OH})_{2}$ or $\mathrm{Ni}(\mathrm{OH})_{2}$, respectively, starts [26] that leads to pseudoadsorption of the metal ion on the nanotubes surface.

The dependences of $\mathrm{Ni}(\mathrm{II})$ and $\mathrm{Cu}(\mathrm{II})$ adsorption on the adjusted $\mathrm{pH}$ values by N-CNTs are shown in Fig. 5 . In acidic media (from $\mathrm{pH}$ 2.0 to $\mathrm{pH} 4.0$ ), a marked rise in adsorption with an increase in $\mathrm{pH}$ was observed; then in the interval of $\mathrm{pH}$ 4.0-8.0 for $\mathrm{Ni}(\mathrm{II})$ or $\mathrm{pH}$ 
4.0-6.5 for $\mathrm{Cu}(\mathrm{II})$, a roughly constant value of adsorption was measured. After that, a sharp elevation in the $\mathrm{Ni}(\mathrm{II})$ and $\mathrm{Cu}(\mathrm{II})$ adsorption took place due to precipitation of nickel and copper hydroxide on the surface. The adsorbed amount of both ions by oxidized samples is higher compared to that by as-prepared nanotubes in the almost whole $\mathrm{pH}$ interval studied. This is explained by additional contribution of the ion exchange to the mechanism of adsorption in the first system (see below).

Figure 6 demonstrates the adsorption isotherms of the Ni(II) and $\mathrm{Cu}(\mathrm{II})$ ions onto as-prepared and oxidized N-CNTs measured at "natural', i.e., non-adjusted $\mathrm{pH}$. In addition, the changes in the equilibrium $\mathrm{pH}$ of suspensions because of adsorption of heavy metal ions are depicted in Fig. 6. It is seen that the shape of adsorption isotherms is similar: a stepwise rise in adsorption with increasing the equilibrium concentration of the nickel or copper ions, with a tendency to reach a plateau value of the adsorbed amount (Langmuir type isotherm); the maximum adsorbed amount slightly increases while moving from as-prepared $(28 \mathrm{mg} / \mathrm{g}$ for $\mathrm{Cu}$ and $35 \mathrm{mg} / \mathrm{g}$ for $\mathrm{Ni})$ to oxidized $(36 \mathrm{mg} / \mathrm{g}$ for $\mathrm{Cu}$ and $40 \mathrm{mg} / \mathrm{g}$ for $\mathrm{Ni}$ ) samples; adsorption of these ions gives a moderate lowering in the solution $\mathrm{pH}$ for pristine N-CNTs (up to $1.0-1.5 \mathrm{pH}$ unit) and a marked drop for oxidized sample (about $2.5 \mathrm{pH}$ unit) as a result of ion exchange of surface $\mathrm{H}^{+}$ions for adsorbing nickel or copper ions. Note that the plateau-adsorbed values by pristine and oxidized samples do not differ substantially.

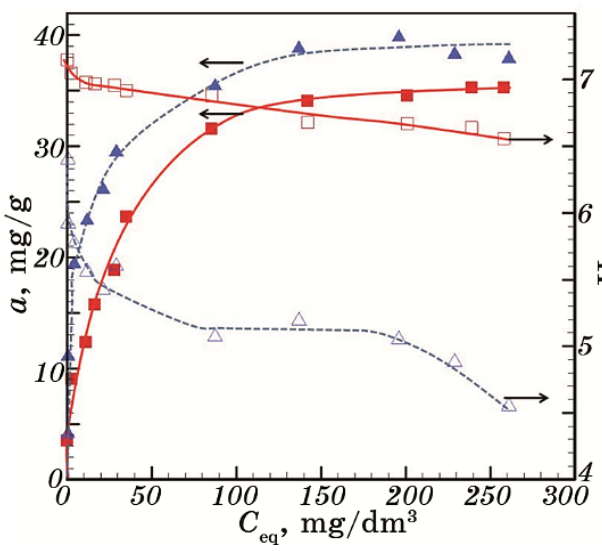

$a$

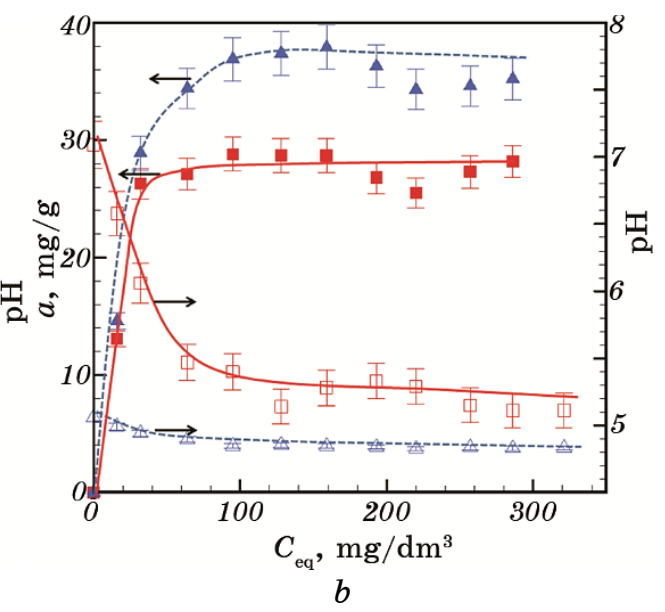

$b$

Fig. 6. Adsorption isotherms of the $\mathrm{Ni}(\mathrm{II})(a)$ and $\mathrm{Cu}(\mathrm{II})(b)$ ions by the asprepared (squares) and oxidized (triangles) N-CNTs at 'natural' $\mathrm{pH}$ of the suspension ( $\mathrm{pH} 5.0-6.0)$. In addition, the changes in the equilibrium $\mathrm{pH}$ of a $0.1 \%$ suspension because of ions' adsorption are also shown. 
Quite different changes in the equilibrium $\mathrm{pH}$ of N-CNT suspensions having various adjusted $\mathrm{pH}$ values and different adsorbed amounts of $\mathrm{Ni}$ (II) and $\mathrm{Cu}$ (II) ions were found. Addition of N-CNTs to the salt solutions in acidic media with adjusted $\mathrm{pH}$ (in the range of approximately $\mathrm{pH} 2-5$ for as-prepared and $\mathrm{pH} 2-4$ for oxidized samples) results in a measurable increase of the suspension equilibrium $\mathrm{pH}$. For example, adsorption of $\mathrm{Ni}(\mathrm{II})$ in amount of $7.14 \mathrm{mg} / \mathrm{g}$ or $17.8 \mathrm{mg} / \mathrm{g}$ resulted in the rise of the adjusted/initial $\mathrm{pH}$ from 2.83 to 3.48 or 5.23 to 6.18 in the $0.1 \%$ N-CNT suspension, respectively (see Table 1). Similar rise of $\mathrm{pH}$ (up to $1.5-2.0 \mathrm{pH}$ units) was observed in the oxidized N-CNT suspensions in acidic media in the event of either $\mathrm{Ni}(\mathrm{II})$ or $\mathrm{Cu}(\mathrm{II})$ adsorption. We attribute this rise in $\mathrm{pH}$ to the transfer of $\mathrm{H}^{+}$ions from the solution to pyridine $\mathrm{N}$-atoms on the N-CNTs surface, i.e., we can hardly imagine the substitution of surface hydrogen ions by adsorbing copper ions in the presence of excess $\mathrm{H}^{+}$ions (low $\mathrm{pH}$ ) in the system. At higher $\mathrm{pH}$ values, this effect is overcompensated by the ion exchange of $\mathrm{Cu}(\mathrm{II})$ with surface $\mathrm{H}^{+}$ions that gives a moderate drop in $\mathrm{pH}$ for pristine N-CNTs and a much bigger decrease of $\mathrm{pH}$ (up to $2.5 \mathrm{pH}$ units) for the oxidized samples (Table). In alkali media, an additional release of $\mathrm{H}^{+}$ ions occurs because of hydrolysis and precipitation of $\mathrm{Ni}$ (II) or $\mathrm{Cu}(\mathrm{II})$ ions in the form of hydroxides.

Obviously, different mechanisms are governing the adsorption of $\mathrm{Ni}(\mathrm{II})$ and $\mathrm{Cu}(\mathrm{II})$ ions by N-CNTs. A release of $\mathrm{H}^{+}$ions from the oxidized N-CNTs testifies the essential role of the ion exchange in binding the nickel or copper ions for this adsorbent; this mechanism

TABLE. Changes of the equilibrium $\mathrm{pH}\left(\mathrm{pH}_{\mathrm{eq}}\right)$ of $0.1 \% \mathrm{~N}-\mathrm{CNT}$ suspensions containing $29-31 \mathrm{mg}$ of the $\mathrm{Ni}(\mathrm{II})$ or $\mathrm{Cu}(\mathrm{II})$ ions per $1 \mathrm{~g}$ carbon nanotubes at various initial/adjusted $\mathrm{pH}\left(\mathrm{pH}_{\mathrm{adj}}\right)$ of the system (selected data).

\begin{tabular}{|c|c|c|c|c|c|c|c|c|c|c|c|}
\hline \multicolumn{6}{|c|}{ Adsorption of $\mathrm{Ni}(\mathrm{II})$} & \multicolumn{6}{|c|}{ Adsorption of $\mathrm{Cu}(\mathrm{II})$} \\
\hline \multicolumn{3}{|c|}{ Pristine N-CNTs } & \multicolumn{3}{|c|}{ Oxidized N-CNTs } & \multicolumn{3}{|c|}{ Pristine N-CNTs } & \multicolumn{3}{|c|}{ Oxidized N-CNTs } \\
\hline $\mathrm{H}_{\text {adj. }}$ & $\mathrm{pH}_{\text {eq. }}$ & $\begin{array}{c}a, \\
\mathrm{mg} / \mathrm{g}\end{array}$ & & & & $\mathrm{pH}_{\text {adj. }}$ & $\mathrm{pH}_{\text {eq. }}$ & & $\mathrm{pH}_{\text {adj. }}$ & $\mathrm{pH}_{\text {eq. }}$ & $\begin{array}{c}a, \\
\mathrm{mg} / \mathrm{g}\end{array}$ \\
\hline & 3.48 & 7.14 & 2.84 & 3.18 & & 2.02 & & & 2.03 & 2.09 & 12.1 \\
\hline & & & & & & & & & & 2.99 & \\
\hline & 18 & 17 & 6 & & & 4.20 & & & 84 & & 32 \\
\hline 6.58 & 6.50 & 17.7 & 6.38 & & 18.4 & 5.76 & 5.73 & 3.3 & 5.95 & 3.96 & 31.5 \\
\hline 3 & 04 & 18.3 & 8.2 & & & 6.71 & 5.86 & & 6.58 & 5.00 & 54.6 \\
\hline 8.77 & .64 & 20.2 & 8.77 & 6.58 & 27.7 & 8.96 & 6.62 & 59.9 & 8.86 & 6.45 & 60.9 \\
\hline 11.3 & 9.70 & 28.8 & 11.2 & 7.74 & 28.2 & & & & & & \\
\hline
\end{tabular}


is supported by the FTIR data (Fig. 4). To estimate the contribution of this factor, we have compared the adsorbed amounts with changes of the solution $\mathrm{pH}$, i.e., the concentration of the substituted $\mathrm{H}^{+}$ ions by copper or nickel ions from the surface. For example, adsorption of $31.5 \mathrm{mg} / \mathrm{g}$ or $4.9 \cdot 10^{-4} \mathrm{~mole} / \mathrm{g} \mathrm{Cu}$ (II) by oxidized N-CNTs resulted in a decrease of solution $\mathrm{pH}$ from 5.95 to 3.96 , which corresponds to an appearance of roughly $10^{-4} \mathrm{M}$ ions in the suspension of concentration $10 \mathrm{mg} \mathrm{CNT} / 10 \mathrm{~cm}^{3}$ or $1.0 \mathrm{~g} \mathrm{CNT} / \mathrm{dm}^{3}$. This means that a part (approximately $20 \%$ ) of $\mathrm{Cu}$ (II) ions is adsorbed via ion exchange with $\mathrm{H}^{+}$ions of the surface.

At the same time, the majority of copper ions are bound to the CNTs because of other type interactions, probably donor-acceptor interaction between the free electron pair of $\mathrm{N}$-atoms of the surface and vacant $d$-orbital of the adsorbing ions. Similar calculations have shown that adsorption of $16.3 \mathrm{mg} / \mathrm{g}$ or $2.8 \cdot 10^{-4} \mathrm{~mole} / \mathrm{g} \mathrm{Ni}$ (II) by pristine N-CNTs, which decreased the solution $\mathrm{pH}$ from 8.32 to 7.04, resulted in appearance of $1.5 \cdot 10^{-7}$ mole $\mathrm{H}^{+}$ions in a suspension with $10 \mathrm{mg} \mathrm{N}-\mathrm{CNTs}$ or $1.5 \cdot 10^{-5}$ mole $\mathrm{H}^{+}$ions per $1 \mathrm{~g}$ nanotubes. This comprises only $5 \%$ of the adsorbed amount of nickel ions. In the event of oxidized N-CNT adsorption of $18.4 \mathrm{mg} / \mathrm{g}$ of $\mathrm{Ni}(\mathrm{II})$, the drop in the system $\mathrm{pH}$ reached $1.12 \mathrm{pH}$ unit, from 6.38 to 5.26 which corresponds to an increase in the $\mathrm{H}^{+}$concentration from $4 \cdot 10^{-6} \mathrm{~mole} / \mathrm{dm}^{3}$ to $2 \cdot 10^{-5} \mathrm{~mole} / \mathrm{dm}^{3}$, which is less than $10 \%$ of the adsorbed amount of $\mathrm{Ni}$ (II) $\left(3.2 \cdot 10^{-4} \mathrm{~mole} / \mathrm{g}\right)$.

\section{CONCLUSIONS}

We describe and discuss in this paper the laws and mechanisms of adsorption of $\mathrm{Ni}(\mathrm{II})$ and $\mathrm{Cu}(\mathrm{II})$ ions by well characterized pristine and oxidized N-doped multi-walled carbon nanotubes (N-CNTs).

As demonstrated, the N-CNTs can serve for extraction of $\mathrm{Ni}(\mathrm{II})$ and $\mathrm{Cu}(\mathrm{II})$ ions from aqueous solution. The specific adsorption values (28-35 mg/g for copper and 35-40 mg/g for nickel) and degree of extraction (10-99\% from solutions of equilibrium concentration of $580-5.0 \mathrm{mg} / \mathrm{dm}^{3}$ ) of these ions are comparable with those for the non-oxidized and oxidized multiwalled carbon nanotubes described in the literature. The main laws of adsorption observed can be summarized as follow: (i) adsorption reaches equilibrium value within $60 \mathrm{~min}$; (ii) the degree of extraction of ions sharply increases with a decrease in their concentration, (iii) adsorption of $\mathrm{Cu}(\mathrm{II})$ and $\mathrm{Ni}$ (II) by as-prepared N-CNTs results in a moderate decrease in the $\mathrm{pH}$ value of the suspension (up to $1.5 \mathrm{pH}$ unit) and in a considerable lowering the $\mathrm{pH}$ for oxidized samples (up to $2.5 \mathrm{pH}$ unit); (iv) the adsorption isotherms can be described by the Langmuir equation; (v) at $\mathrm{pH} \geq 6.5$ for $\mathrm{Cu}$ (II) and $\mathrm{pH} \geq 8.0$ for $\mathrm{Ni}(\mathrm{II})$ a sharp in- 
crease in adsorption took place. We consider that the laws described can be explained by accounting three types of binding of these ions to the N-CNTs surface: (i) ion-exchange between $\mathrm{Cu}(\mathrm{II})$ or $\mathrm{Ni}$ (II) ions and $\mathrm{H}^{+}$of surface functional groups, and this effect is more pronounced for the oxidized N-CNTs sample but does not make decisive contribution into adsorption; (ii) donor-acceptor interaction between the vacant $d$-orbital of adsorbing transition metal ions and $\mathrm{N}$-atoms of the nanotubes matrix, and this effect seems to be universal and playing major role in the binding of transition metal ions to both as-prepared and oxidized samples surface; (iii) precipitation of $\mathrm{Cu}(\mathrm{OH})_{2}$ or $\mathrm{Ni}(\mathrm{OH})_{2}$ onto carbon nanotubes surface at hydroxides precipitation $\mathrm{pH}$ values.

\section{REFERENCES}

1. X. Ren, C. Chen, M. Nagatsu, and X. Wang, Chem. Eng. J., 170, Nos. 2-3: 395 (2011); https://doi.org/10.1016/j.cej.2010.08.045.

2. Y.-H. Li, S. Wang, J. Wei, X. Zhang, C. Xu, Z. Luan, D. Wu, and B. Wei, Chem. Phys. Lett., 357, Nos. 3-4: 263 (2002); https://doi.org/10.1016/S0009-2614(02)00502-X.

3. K. Pyrzynska and M. Bystrzejewski, Colloids Surf. A, 362: 102 (2010); https://doi.org/10.1016/j.colsurfa.2010.03.047.

4. M. V. Manilo, Z. Z. Choma, and S. Barany, Colloid J., 79, No. 2: 212 (2017); https://doi.org/10.1134/S1061933X17020053.

5. Y.-H. Li, S. Wang, Z. Luan, J. Ding, C. Xu, and D. Wu, Carbon, 41: 1057 (2003); https://doi.org/10.1016/S0008-6223(02)00440-2.

6. Ch. Chen and X. Wang, Ind. Eng. Chem. Res., 45, No. 26: 9144 (2006); https://doi.org/10.1021/ie060791z.

7. Sh. Yang, J. Li, D. Shao, J. Hu, and X. Wang, J. Hazard. Mater., 166, No. 1: 109 (2009); https://doi.org/10.1016/j.jhazmat.2008.11.003.

8. M. Kandah and J.-L. Meunier, J. Hazad. Mater., 146, Nos. 1-2: 283 (2007); https://doi.org/10.1016/j.jhazmat.2006.12.019.

9. Ch. Lu and Ch. Liu, J. Chemical Technology and Biotechnology, 81, No. 12: 1932 (2006); https://doi.org/10.1002/jctb.1626.

10. F. Giannakopoulou, C. Haidouti, D. Gasparatos, I. Massasand, and G. Tsiakatouras, Desalination and Water Treatment, 57, No. 25: 11623 (2016); https://doi.org/10.1080/19443994.2015.1042069.

11. A. Stafiej and K. Pyrzynska, Separation and Purification Technology, 58: 49 (2007); https://doi.org/10.1016/j.seppur.2007.07.008.

12. L. Vanyorek, G. Muranszky, B. Fiser, E. Sikura, Zs. Hutkai, and B. Viskolcz, J. Disp. Sci. Techn., 40: 1 (2019); https://doi.org/10.1080/01932691.2019.1637757.

13. D. A. Bulushev, A. L. Chuvilin, V. I. Sobolev, S. G. Stolyarova, Y. V. Shubin, I. P. Asanov, A. V. Ishchenko, G. Magnani, M. Riccò, A. V. Okotrub, and L. G. Bulusheva, J. Mat. Chem. A, 5: 10574 (2017); https://doi.org/10.1039/C7TA02282D.

14. G. P. Rao, Ch. Lu, and F. Su, Separ. Purfic. Techn., 58: 224 (2007); https://doi.org/10.1016/j.seppur.2006.12.006. 
15. M. A. Salam, Gh. Al-Zhrani, and S. A. Kosa, Comptes Rendus Chimie, 15, No. 5: 398 (2012); https://doi.org/10.1016/j.crci.2012.01.013.

16. A. Gadhave and J. Waghmare, International J. Chemical Sci. Applications, 5, No. 2: 56 (2014).

17. Zh. Gao, T. J. Bandosz, Z. Zhao, M. Hanand, and J. Qiu, J. Hazardous Materials, 167, Nos. 1-3: 357 (2009); https://doi.org/10.1016/j.jhazmat.2009.01.050.

18. L. Vanyorek, R. Mészáros, and S. Bárány, Colloids and Surfaces A, 448: 140 (2014); https://doi.org/10.1016/j.colsurfa.2014.01.078.

19. S. Barany, N. Kartel', and R. Meszaros, Colloid J., 76: 509 (2014); https://doi.org/10.1134/S1061933X14050020.

20. S. Gomez, N. M. Rendtorff, E. F. Aglietta, Y. Sakka, and G. Suarez, Applied Surface Sci., 379: 264 (2016); https://doi.org/10.1016/j.apsusc.2016.04.065.

21. K. Csobán, M. Párkányi-Berka, P.Joó, and Ph. Behrab, Colloids and Surfaces A: Physicochemical and Engineering Aspects, 141, No. 3: 347 (1998); https://doi.org/10.1016/S0927-7757(98)00244-1.

22. K. Csobán and P.Joó, Colloids and Surfaces A: Physicochemical and Engineering Aspects, 151, Nos. 1-2: 97 (1999); https://doi.org/10.1016/S0927-7757(98)00421-X.

23. J. Lakatos, S. D. Brown, and C. E. Snape, Fuel, 81, No. 5: 691 (2002); https://doi.org/10.1016/S0016-2361(01)00159-4.

24. M. Ajmal, R. A. K. Rao, R. Ahmad, J. Ahmad, and L. A. K. Rao, J. Hazardous Materials, 87, Nos. 1-3: 127 (2001); https://doi.org/10.1016/S0304-3894(01)00234-5.

25. M. V. Manilo, Z. Z. Choma, and S. Barany, Colloid J., 79, No. 2: 212 (2017); https://doi.org/10.1134/S1061933X17020053.

26. K. A. Burkov, L. S. Lilič, and L. G. Sillien, Acta Chem. Scandinavia, 19: 14 (1965); https://doi.org/10.3891/acta.chem.scand.19-0014.

27. D. Novak-Adamic, B. Cosovic, H. Bilinski, and M. Branica, J. Inorg. Nucl. Chem., 35, No. 7: 2371 (1973); https://doi.org/10.1016/00221902(73)80303-3. 